\title{
Trona Causes Fetal Loss in Pregnant Rat via an Oestrogen-dependent Mechanism
}

\author{
AF Ajayi, RE Akhigbe
}

\begin{abstract}
Background: There is a claim in folklore medicine in Nigeria that trona (a sesquicarbonate or hydrated carbonate of sodium) causes fetal loss. However, this has not been substantiated or refuted by any scientific evidence.

Aim: This study evaluates whether or not trona causes fetal loss in pregnant female Wistar rats.

Methods: Pregnant Wistar rats of comparable weights were randomized into three groups. Group A (control) was given a single dose of $1.25 \mathrm{~mL} / \mathrm{kg}$ body weight of lime while groups $B$ and C were given 250 $\mathrm{mg} / \mathrm{kg}$ and $500 \mathrm{mg} / \mathrm{kg}$ body weight of trona, respectively.

Results: There was no significant difference in the body weight gained across all the groups. The dose of $250 \mathrm{mg} / \mathrm{kg}$ body weight of trona decreased the number of live fetus, while $500 \mathrm{mg} / \mathrm{kg}$ body weight produced no live fetus; $250 \mathrm{mg} / \mathrm{kg}$ and $500 \mathrm{mg} / \mathrm{kg}$ body weight of trona led to fetal loss rate of $83.33 \%$ and $100 \%$, respectively. Trona also reduced the concentrations of serum progesterone and cholesterol, and increased serum oestradiol.

Conclusion: This study revealed that trona causes fetal loss. This is possibly via an oestrogen-dependent mechanism, and attributed to the chemical constituents of trona.
\end{abstract}

Keywords: Body weight, cholesterol, fetal loss, oestradiol, progesterone, trona

\section{La Trona Causa Pérdida Fetal en Ratas Embarazadas a Través de un Mecanismo Dependiente de Estrógenos \\ AF Ajayi, RE Akhigbe}

\begin{abstract}
RESUMEN
Antecedentes: La medicina folklórica en Nigeria sostiene que la trona (sesquicarbonato o carbonato de sodio hidratado) causa pérdida fetal. Sin embargo, esto no ha sido fundamentado o refutado con evidencias cientificas.

Objetivo: Este estudio evalúa si es cierto o no que la trona causa pérdida fetal en ratas Wistar hembras embarazadas.

Métodos: Ratas Wistar embarazadas de peso similar fueron distribuidas en tres grupos de manera aleatoria. El grupo A (control) recibió una sola dosis de cal de $1.25 \mathrm{~mL} / \mathrm{kg}$ de peso corporal, mientras que el grupo B y el grupo C recibieron trona en dosis de $250 \mathrm{mg} / \mathrm{kg}$ y $500 \mathrm{mg} / \mathrm{kg}$ de peso corporal, respectivamente.

Resultados: No hubo diferencias significativas en el peso corporal obtenido a través de todos los grupos. La dosis de trona de $250 \mathrm{mg} / \mathrm{kg}$ por peso corporal disminuyó el número de fetos vivos, mientras que 500 $\mathrm{mg} / \mathrm{kg}$ de peso corporal no produjo fetos vivos; $250 \mathrm{mg}$ y $500 \mathrm{mg} / \mathrm{kg}$ de peso corporal de trona llevaron la tasa de pérdida fetal a $83.33 \%$ y el $100 \%$, respectivamente. La trona también redujo las concentraciones de progesterona sérica y colesterol, y aumentó el estradiol sérico.

Conclusión: Este estudio reveló que la trona causa pérdida fetal. Esto ocurre posiblemente mediante un mecanismo estrógeno-dependiente, y es atribuible a los componentes químicos de la trona.
\end{abstract}

Palabras claves: Peso corporal, colesterol, pérdida fetal, estradiol, progesterona, trona

West Indian Med J 2016; 65 (1): 83

From: Department of Physiology, College of Health Sciences, Ladoke Akintola University of Technology, Ogbomoso, Oyo State, Nigeria.
Correspondence: Dr RE Akhigbe, Department of Physiology, Faculty of Basic Medical Sciences, College of Health Sciences, Ladoke Akintola University of Technology, Ogbomoso, Oyo state, Nigeria. E-mail: akhigberoland@ gmail.com 


\section{INTRODUCTION}

Several methods have been employed as measures of family planning. These include contraception and abortion (1). None of these is without side effects. Numerous factors influence the choice of family planning method. In the developing countries, important factors are cost and easy accessibility, which have led to the use of traditional methods of contraception (2). Traditional medicine has been used for the control of fertility in Nigeria for many years. This has led to continued interest among researchers in evaluating natural products used for fertility control (3-11); a common substance used locally is trona.

Trona, a sesquicarbonate or hydrated carbonate of sodium, is popularly called 'Kanwa' in the northern part of Nigeria where it mostly occurs as a deposit of saline lakes (12). There are various varieties of trona; however, these have similar properties. Isolated chemical constituents are high amounts of sodium and calcium ions and low iron, potassium, magnesium, zinc, manganese, carbonates, sulphate, bicarbonates and chloride ions (13). Although, trona is locally used for fertility control in Nigeria orally, there has been no scientific documentation to support this. This study thus evaluates the hormonal effects of trona, and its potential to cause fetal loss.

\section{SUBJECTS AND METHODS}

Trona was obtained from a local market in Ogbomoso and authenticated by AF Ajayi of the Department of Physiology, Ladoke Akintola University of Technology (LAUTECH), Ogbomoso, Oyo state, Nigeria.

Healthy male and female rats (of Wistar strain) of proven fertility and of comparable weights were obtained from the Animal House of the Department of Physiology, LAUTECH, Nigeria. All animals were housed in clean, stainless steel cages placed in well-ventilated room conditions (temperature: $28^{\circ} \mathrm{C}-$ $31{ }^{\circ} \mathrm{C}, 12$-hour light-dark cycle, humidity of $45 \%-50 \%$ ). They were also allowed to feed on pellets (Bendel Feeds and Flour Mill, Ewu, Edo, Nigeria) and water ad libitum. The animals were acclimatized for two weeks. This study was carried out following approval from the Departmental Ethics Committee on the use and care of experimental animals, and animals were handled according to the guidelines of the National Institutes of Health on the Care and Use of Laboratory Animals (14).

\section{Preparation of trona solution}

The sample was carefully grounded with mortar and pestle, and sieved. Sample specimens were taken to the laboratory of Food Science and Engineering, LAUTECH, for extraction using lime and stored in a bottle under room temperature until used. Two hundred grams of trona was dissolved in one litre of lime to give a concentration of $200 \mathrm{mg} / \mathrm{mL}$. The solution was reconstituted to give the required doses of 250 and 500 $\mathrm{mg} / \mathrm{kg}$ body weight that was used in the study. The method of preparation and doses used in the study are as commonly used locally.

\section{Determination of fetal loss}

This was done as previously described $(3,15)$. A fter the acclimatization period, vaginal smears were examined to study their oestrous cycle and ascertain the readiness for mating. Female rats were paired overnight with the male counterparts (ratio 1:1) in the stainless steel cages that provided free access to food and water. Again, the vaginal smear was examined every morning for presence of spermatozoa using a binocular microscope. The day on which spermatozoa was detected on vaginal smear was considered day 0 of pregnancy. Pregnant rats were randomized into three group (A, B and C) consisting of six rats each. During the $15^{\text {th }}-20^{\text {th }}$ day (organogenetic period) of pregnancy, group $\mathrm{A}$, which is the control group, was given a single dose of $1.25 \mathrm{~mL} / \mathrm{kg}$ body weight of lime with the aid of a metal oropharyngeal cannula, while groups $\mathrm{B}$ and $\mathrm{C}$ were given $250 \mathrm{mg} / \mathrm{kg}$ and $500 \mathrm{mg} / \mathrm{kg}$ body weight of trona extract, respectively. Body weight and behavioural changes were monitored daily throughout the experimental period. Twenty-four hours after the last dose (on the $21^{\text {st }}$ day), all the rats from each group were laparotomized under ether anaesthesia, and the following parameters were recorded: number of live fetuses, number of fetal loss, \% fetal loss [(number of fetal loss/number of rats used) $\times 100]$. Blood samples were also collected for hormonal assay.

Standard assay kits for hormonal assay were used. Assay kits for hormonal assay (Randox Laboratory, Inc., Co Antrim, United Kingdom for cholesterol assay and Diagnostic Automation, Inc., Calabasas, CA, USA, for progesterone and oestradiol assay) were used. Serum progesterone oestradiol and cholesterol were quantitatively determined by enzymelinked immunosorbent assay (ELISA) following the procedure outlined in the manufacturer's protocol version which adopted the principle of Tietz (16). The intra- and inter-assay variability was $8.1 \%$.

The body weights of the experimental animals were determined and recorded on the first day (initial weight) and on the last day of the experiment prior to laparotomy (final weight). The body weight gain of each rat was evaluated as the difference between the initial and final weight.

\section{Statistical analysis}

The mean of six replicates \pm standard error of mean (SEM) was calculated for all values (17). Comparisons between the control and experimental groups were done using the Student $t$-test. Differences were considered statistically significant at $p<0.05$.

\section{RESULTS}

There was no significant difference in the body weight gained across all the groups (Table 1). Clinical toxicity symptoms such as respiratory distress, salivation, weight loss, dull eyes, diarrhoea and change in the appearance of fur were not observed in the animals. There was also no case of mortality in the experimental rats used. This suggests that trona was not clinically toxic to the experimental animals. 
Table 1: Effect of administration of trona on body weight gain of pregnant rats

\begin{tabular}{lccc}
\hline Weight (in grams) & Control & $\mathbf{2 5 0} \mathbf{~ m g} / \mathbf{k g}$ & $\mathbf{5 0 0} \mathbf{~ m g} / \mathbf{k g}$ \\
\hline Initial weight & $154.167 \pm 1.17$ & $155.550 \pm 1.12$ & $157.627 \pm 1.35$ \\
Final weight & $192.833 \pm 1.33$ & $194.620 \pm 1.95$ & $194.167 \pm 1.20$ \\
Body weight gain & $38.666 \pm 1.29$ & $39.070 \pm 1.32$ & $36.54 \pm 1.24$ \\
\hline
\end{tabular}

Data represent mean $\pm \operatorname{SEM}(n=6)$

Treatment with $250 \mathrm{mg} / \mathrm{kg}$ body weight of the trona decreased the number of live fetuses by $60 \%$, while no live fetus was observed in the $500 \mathrm{mg} / \mathrm{kg}$ body weight treated animals. Administration of 250 and $500 \mathrm{mg} / \mathrm{kg}$ body weight of trona resulted in $83.33 \%$ and $100 \%$ fetal loss, respectively, as indicated by the number of animals with dead fetuses during the laparotomy (Table 2).

Table 2: Effect of trona on some abortifacient parameters of pregnant rats

\begin{tabular}{llll}
\hline Parameters & \multicolumn{1}{c}{ Control } & $\mathbf{2 5 0} \mathbf{~ m g} / \mathbf{k g}$ & $\mathbf{5 0 0} \mathbf{~ m g} / \mathbf{k g}$ \\
\hline Mean of live fetus & $6.00 \pm 0.00$ & $2.40 \pm 0.25^{*}$ & $0.00^{*}$ \\
Mean of dead fetus & 0.00 & $4.40 \pm 0.25^{*}$ & $6.00 \pm 1.23^{*}$ \\
No. of fetal loss & 0 & 5 & 6 \\
\% fetal loss & 0.00 & 83.33 & 100.00 \\
\hline
\end{tabular}

Data represent mean $\pm \operatorname{SEM}\left(\mathrm{n}=6,{ }^{*} p<0.05\right)$

Administration of trona significantly decreased the concentrations of serum progesterone and cholesterol, and increased serum oestradiol (Figure).

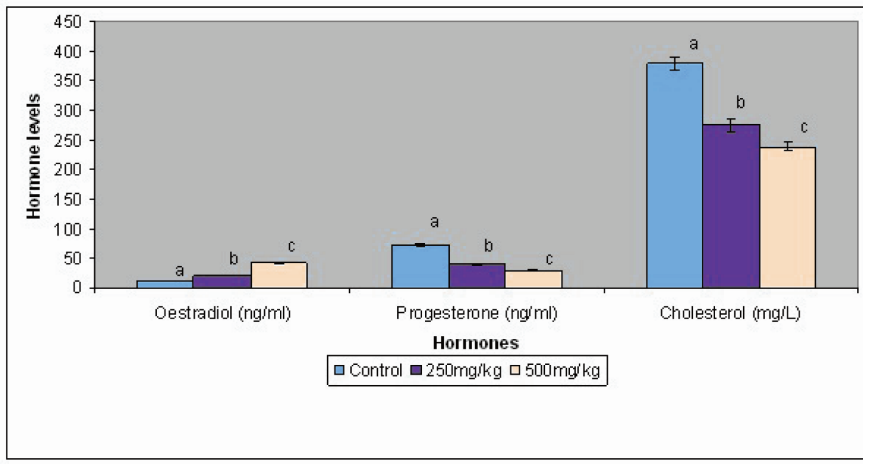

Figure: Effect of administration of trona on some reproductive hormones of pregnant rats.

Bars carrying different letters on each parameter are significantly different at $p<0.05$.

\section{DISCUSSION}

The findings of this study revealed an interesting measure of fertility control. Pregnancy can be disrupted by interfering with the process of implantation or the mitotic division of the fetus with resultant embryonic loss $(2,18)$.

The decrease in the number of live fetuses as well as increased number of dead fetuses seen in the present study is an indication that trona has the biological activity to cause fetal loss. A higher number of fetal loss in the $500 \mathrm{mg} / \mathrm{kg}$ body weight-treated is a pointer to the dose-dependent effect of trona in causing fetal loss. This finding is in consonance with previous studies that documented the potential phytochemicals in causing fetal loss $(3,5,15)$. Observations from this study also corroborate previous documentation of Alawa et al (13) that reported the contractile effects of trona.

The reduced levels of cholesterol and progesterone, and concomitant rise in oestradiol seen in the study could explain the activity of trona to cause fetal loss. Progesterone, a hormone of pregnancy, promotes endometrial function, nourishes the fertilized ovum, and keeps the uterus relaxed to carry pregnancy to term. The fall in serum progesterone level following trona administration may explain, at least in part, the fetal loss observed in the study (19). The rise in oestradiol level in the study agrees with a previous study (20) that associated antifertility extracts with their oestrogenic activity. The elevated oestradiol level possibly resulted in an increase in protein synthesis, uterine weight, water uptake and retention of fluid, leading to ballooning of the uterus (21). It may also have caused uterotrophic changes and vaginal opening (22), rise in the uterine content of glucose, cholesterol, glycogen, alkaline phosphatase activity, and increased uterine contractility, thereby producing alterations in the uterine milieu and creating hostile conditions in the uterus (22).

The effect of trona on pregnancy may also be attributed to its chemical constituents, especially the high levels of sodium and calcium ions, which are essential for uterine contraction. A rise in cystolic calcium initiates excitation-contraction coupling in uterine smooth muscle, while sodium increases the force of contraction $(23,24)$. Findings in this study also showed that there was no significant difference in the body weight gained across all the groups. This might suggest that trona is non-toxic.

In conclusion, this study has demonstrated that trona causes fetal loss which may be attributed to the chemical constituents, especially sodium and calcium. This effect is possibly via an oestrogen-dependent mechanism.

\section{REFERENCES}

1. Sanchez-Criado CJE, Tebar M, Padron L. The steroid antagonist RU486 given at pro-oestrus induces hypersecretion of follicle-stimulating hormone from oestrus afternoon to early metoestrus in the rat. Eur J Endocrinol 1997; 137: 281-4.

2. Goonasekera MM, Gunawardana VK, Jayasena K, Mohammed SG, Balasubramaniam S. Pregnancy terminating effect of Jatropha curcas in rats. J Ethnopharmacol 1995; 47: 117-23.

3. Yakubu MT, Bukoye BB. Abortifacient potentials of the aqueous extract of Bambusa vulgaris leaves in pregnant Dutch rabbits. Contraception 2009; 80: 308-13.

4. Akpantah AO, Oremosu AA, Noronha CC, Ekanem TB, Okanlawon AO. Effects of Garcinia kola seed extract on ovulation, oestrous cycle and foetal development in cyclic female Sprague-Dawley rats. Niger J Physiol Sci 2005; 20: 58-62.

5. Yakubu MT, Adeshina AO, Oladiji AT, Akanji MA, Oloyede OB, Jimoh GA et al. Abortifacient potential of aqueous extract of Senna alata leaves in rats. J Reprod Contracept 2010; 21: 163-77. 
6. Ajayi AF, Akhigbe RE. Antifertility activity of Cryptolepis sanguinolenta leaf ethanolic extract in male rats. J Hum Reprod Sci 2012; 5: 437.

7. Ajayi AF, Akhigbe RE, Adewumi OM, Olaleye SB. Haematological evaluation of Cryptolepis sanguinolenta stem ethanolic extract in rats. Int $\mathrm{J}$ Med Biomed Res 2012; 1: 56-61.

8. Ajayi AF, Akhigbe RE, Iyiola TO, Adewumi OM, Olaleye SB. Gastric secretagogue action of Cryptolepis sanguinolenta in the perfused stomach of anesthetized rats. Int J Med Biomed Res 2012; 1: 62-7.

9. Ige SF, Akhigbe RE. The role of Allium cepa on aluminium-induced reproductive dysfunction in experimental male rat models. J Hum Reprod Sci 2012; 5: 200-5.

10. Ige SF, Akhigbe RE, Olaleye SB, Adeyemi JW. Gastroprotective of the methanolic extract of Garcinia kola in rats. Int J Med Biomed Res 2012; 1: $172-8$.

11. Ige SF, Olaleye SB, Akhigbe RE, Akanbi TA, Oyekunle OA, Udoh US. Testicular toxicity and sperm quality following cadmium exposure in rats: ameliorative potentials of Allium cepa. J Hum Reprod Sci 2012; 5: $37-$ 42.

12. Makanjuola AA, Beetlestone JG. Some chemical and mineralogical notes on 'kaun'. J Min Geolo 1975; 10: 1-2.

13. Alawa CBI, Adamu AM, Ehoche OW, Lamidi OS, Oni OO. Performance of Bunaji bulls fed maize stover supplemented with urea and local mineral lick (Kanwa). J Agric Environ 2000; 1: 35-42.

14. National Institutes of Health. Guide for the Care and Use of Laboratory Animals. NIH Publication No. 83-127. Washington, DC, USA: National Research Council; 1985.
15. Salhab AS, Al-Tamimi SO, Gharaibeh MN, Shomaf MS. The abortifacient effects of castor bean extract and ricin A-chain in rabbit. Contraception 1998; 58: 193-7.

16. Tietz NW. Clinical guide to laboratory tests. $3^{\text {rd }}$ ed. Philadelphia: WB Saunders, Co; 1995.

17. Taiwo IA, Adewumi OO, Odeigah PGC. Assessment of Bridelia ferruginea benth for its therapeutic potential in pregnancy-induced impaired glucose tolerance in rats. Int J Med Biomed Res 2012; 1: 49-55.

18. Elbetieha A, Oran SA, Alkofahi A, Darmani H, Raies AM. Fetotoxic potentials of Globularia arabica and Globularia alypum (Globulariaceae) in rats. J Ethnopharmacol 2000; 72: 215-9.

19. Schorge JO, Schaffer I, Halrorson LM. Williams Gynaecology. China: The McGraw-Hill Companies; 2008: 137-40.

20. Gebrie E, Makonnen E, Zerihun L, Debella A. The possible mechanisms for the antifertility actions of the methanolic root extract of Rumex steudelli. Afr Health Sci 2005; 5: 119-25.

21. Rifai N, John J, Albers PSB. Lipids, lipoproteins and apolipoproteins In: Tietz NW, ed. Fundamentals of clinical chemistry. $5^{\text {th }}$ ed. Philadelphia: WB Saunders; 2001: 462-93.

22. Koneri R, Saraswati CD, Balaraman R, Ajeesha EA. Antiimplantation activity of the ethanolic root extract of Momordica cymbalaria Fenzl in rats. Indian J Pharmacol 2007; 39: 90-6.

23. Rogart R. Sodium channels in nerve and muscles membrane. Annu Rev Physiol 1981; 43: 711.

24. Suzuki H, Chen G. Endothelium derived hyperpolarizing factor (EDHF) on endogenous potassium channel opener. News Physiol Sci 1990; 5: $212-5$. 